\title{
Effect of Socio-cultural Factors on Women Entrepreneurship Development in Kaduna State
}

\author{
Ahmed Hussaini Giwa, Abubakar Mohammed Babakatun* \\ Department of Business Administration, College of Business and Management Studies (CBMS), Kaduna Polytechnic, Kaduna \\ Email address: \\ Ahmadgiwa4@gmail.com (A. H. Giwa) \\ ${ }^{*}$ Corresponding author \\ To cite this article: \\ Ahmed Hussaini Giwa, Abubakar Mohammed Babakatun. Effect of Socio-cultural Factors on Women Entrepreneurship Development in \\ Kaduna State. Journal of Human Resource Management. Vol. 7, No. 3, 2019, pp. 57-65. doi: 10.11648/j.jhrm.20190703.11
}

Received: August 27, 2019; Accepted: September 21, 2019; Published: October 15, 2019

\begin{abstract}
Women participation in economic development has been identified to be of importance, most especially in the area of entrepreneurship. However, women the world over play a substantial role in the socio- economic and political development of any country. Given this, the current study examined the effect of socio-cultural factors on women entrepreneurship development in Kaduna state. The specific objectives of the study include: to examine the effect of religion on women entrepreneurship development in Kaduna State; to examine the effect of culture on women entrepreneurship development in Kaduna State; and to examine the effect of gender roles on women entrepreneurship development in Kaduna State. Using descriptive survey research design, data were collected from 332 women entrepreneurs in Kaduna metropolis and then analyzed via correlation and regression analyses techniques to examine the cause, effect, strength and degree of the relationship between socio-cultural factors and women entrepreneurship development. The study found that there is a significant relationship between socio-cultural factors and women entrepreneurship development in Kaduna metropolis, indicating significant relationships between religion and women entrepreneurship, between culture and women entrepreneurship and between gender role and women entrepreneurship development in Kaduna metropolis. The study recommends that women entrepreneurs in Kaduna metropolis should be proactive in doing business by bearing in mind various socio-cultural factors such as religion, culture and gender roles that may hinder the smooth running of their businesses.
\end{abstract}

Keywords: Culture, Gender Role, Kaduna Metropolis, Religion, Women Entrepreneurship

\section{Introduction}

Women participation in economic development has been identified to be indispensable, most especially in the area of entrepreneurship. However, women the world over play a substantial role in the socio- economic and political development of any country. The existing literature in the entrepreneurship research field (see [1-2] state that literatures on entrepreneurship have vividly acknowledged the drive by women to become economically active and independent and their contributions have significant effects on the labour market in economies of the world. Eijdenberg and Masurel [3] state that people in developing economies are in most cases forced by poverty, survival and lack of jobs to become entrepreneurs. While in developed economies, entrepreneurial activities spring up as a result of exploitation of an opportunity and innovation to start a business.
Fundamentally, People exist within some cultural frameworks and social beliefs, as well as values which determine the ways and manner in which they live. In view of entrepreneurship, the socio-cultural values can be defined as consisting of all those factors of the social system which impact positively and negatively on their quest to become entrepreneurs. Hence, the socio-cultural system in Nigeria is gender discriminatory. The traditional belief about the status and role of women in society does not allow women to participate in serious economic activities and this to some extent serves as a constraint on the entrepreneurial engagement of women in Nigeria. According to Akpor [4], the culture of the major tribe; Hausa-Fulani still presents a woman as a person who is forbidden to interact publicly particularly with men. Subcultures within the cultural context such as regional, ethnicity and religion shape individuals' perception and value system towards entrepreneurship ([5, 
6]). For example, Yusuf [7] examined gender bias and sub culture like regional, ethnicity and religious practices within the context of national culture that affect women entrepreneurs in developing countries and found that gender, ethnicity and religion play important role in entrepreneurship development and how women entrepreneurs are perceived and valued. In support of this view, Halkias et al. [8] opined that gender bias and cultural beliefs hamper economic potentials of women as entrepreneurs and impact negatively on development of enterprise, productivity, competitiveness and reduced economic growth. Issues of gender discrimination, particularly in developing economies, occasioned by socio-cultural factors have significant influence on entrepreneurial engagement of women [9-10].

However, the ratio of growth of women entrepreneurs in developing countries has called for the attention of both the academic and other Non-Governmental Organizations. Donor organizations, international public institutions, national and local governments, NGOs, private companies, charity organizations, knowledge institutions and business associations have initiated various programs and policies to develop, promote and sustain women entrepreneurship in Nigeria. These organizations initiated a lot of programs such as capacity building for entrepreneurial skills, strengthening women networks, provision of finance and training etc. In view of these initiatives and programs geared towards promoting and developing women entrepreneurship in Nigeria, women in Nigeria still own and manage fewer number of businesses than men, thereby making them to earn less money, with their businesses growing slower when compared with their male counterparts. Also, Studies by Klapper and Parker [11] and Nukpezah and Blankson [12] revealed that women involvement in the small business enterprises is no longer a new thing because they are now seen to be performing a substantial role in the economic growth and development of many countries by furthering prosperity and lowering poverty.

It has been discovered that while women from the Western and Eastern part of Nigeria are seen in millions operating their own businesses, researches show that socio-cultural factors such as culture, religion, gender etc. are seen to impede the development of women entrepreneurs in Northern part of the country Kaduna state inclusive. In the Northern part of Nigeria, the traditional belief about the status and role of women do not allow women to engage in serious economic activities and hence put a limit on their entrepreneurial engagement and involvement, thus creating a situation where majority of married women in the North rely substantially on their husbands for financial intervention and assistance. This cultural practice therefore, prohibits women from most parts of Northern Nigeria from participating in entrepreneurial activities, which has substantially affected women entrepreneurship in the North.

The main objective of the study is to examine the effect of socio-cultural factors on women entrepreneurship development in Kaduna state. The specific objectives of the study include: examine the effect of religion on women entrepreneurship development in Kaduna State, examine the effect of culture on women entrepreneurship development in Kaduna State and examine the effect of gender roles on women entrepreneurship development in Kaduna State.

This study will be useful to government officials in charge of policy formulation specially as it relates to the involvement of women in entrepreneurial activities in Nigeria using Kaduna State as a reference point. Women entrepreneurs will find this study useful as it will enable them to be aware of developments in entrepreneurship as it affects their participation in entrepreneurial activities. This study will fill the research gaps which have been created due to scanty studies on women entrepreneurship in Kaduna State.

The study will examine the effect of socio-cultural factors on women entrepreneurship development in Kaduna Metropolis, Kaduna state of Nigeria. The study will cover the period 2015 to 2019 .

\section{Concept of Women Entrepreneurship}

According to Goyal and Parkash [13], women entrepreneurship is the women or a group of women who initiate, organize and operate a business enterprise. They also added that the Government of India has defined women entrepreneurs as -an enterprise owned and controlled by women having a minimum financial interest of 51 percent of the capital and giving at least 51 per cent of the employment generated in the enterprise to women and that women Entrepreneur is a person who accepts challenging role to meet her personal needs and become economically independent.

According to Kumar et al. [14], women entrepreneurship is an idea or vision which a woman holds to explore and optimize which could help her create new jobs \& economic empowerment among her fellow beings. Women entrepreneurship is a process of owning and managing a new venture or improving on an existing product (s) or service (s) that create value, assuming the accompanied risks and receiving the resulting rewards and independence [15].

\subsection{Concept of Socio-cultural Factors}

Socio-cultural environment in broad terms consists of both the social system and the culture of a people. It refers primarily to man created intangible elements which affect people's behaviour, relationship, perception and way of life, and their survival and existence. In other words, the socialcultural environment consists all elements, conditions and influences which shape the personality of an individual and potentially affect his attitude, disposition, behaviour, decisions and activities. Such elements include beliefs, values, attitudes, habits, forms of behaviour and life styles of persons as developed from cultural, religious, educational and social conditioning [16]. These elements are learned and are shared by a society and transmitted from generation to generation within that society. Thus, social-cultural environment, in relation to entrepreneurship, can be defined as consisting of all the elements of the social system and 
culture of a people which positively or negatively affect and influence entrepreneurial emergence, behaviour and performance, and entrepreneurship development in general. All such elements which condition the values, thinking and action of an individual with respect to entrepreneurship comprise the social-cultural environment of entrepreneurship.

\subsubsection{Culture}

Hofstede [17] defines culture as "the collective programming of the mind, which distinguishes the members of one human group from another... Culture, in this sense, included systems of values: and values are AfrEduc Res J 250 among the building blocks of Culture [18]. The influence of culture on economic activities of different societies has been investigated since beginning of the 20th century. Weber [19] showed the influence of religion (as component of culture) on the economic performance of the society. Fukuyama [20] also provides evidence that social capital (especially interpersonal trust among the members of society) is a major determinant of the society welfare and prosperity. Inglehart [21] investigates influence of the numerous factors that shape the world value system on the sample of the 65 societies. He found evidence that economic differences are linked with large and pervasive cultural differences, as well as, that culture zones are persistent and long lasting. The main point derived from the studies mentioned above is that culture has a profound impact upon the society's welfare. The cultural orientation of a society reflects the complex interaction of values, attitudes and behaviours displayed by its members [18]. These values, in turn, affect the attitudes of individuals, which again form their behavour choices in any given situation. The continually changing patterns of individual and group behavour eventually influence the society's culture, and the cycle begins again. More specifically, other studies support the notion that culture has a profound influence on the entrepreneurial capacity of a society, and that societies usually do not have homogenous cultural setting.

\subsubsection{Gender}

According to Connell [22], gender refers to a description of masculinity or femininity. McMillan-Capehart (2003), used the resource-based view of the firm to argue that gender diversity at the management and organizational levels can provide a firm with a competitive advantage. According to Leonard et al. [23], gender-based inequities in organizations, are reinforced and justified by stereotypes and biases that describe positive characteristics and therefore a higher status to the males. The term "gender" refers to economic, social and cultural attributes and opportunities associated with being male or female [24]. In almost all societies, women and men differ in their activities and undertakings, regarding access to and control over resources, and participating in decision-making. Riley [25] identified gender as a social institution, cultural construct and power tool. According to Ostergaad [26], the term 'gender' refers to qualitative and interdependent character of women and men's position in society. On the other hand, Sex refers to the biological state of being male or female. There is a danger to confuse "gender" with "women". Sen (1999) [27] posited that the concept of gender is not limited to the male or female species but goes further to assess the relations between them. As are constantly being renegotiated in the context of changing political, economic, social and cultural environments at the local, national and supra national levels.

Gender relations refer to a complex system of personal and social relations of domination and power through which women, men are socially created and maintained, and through which they gain access to power and material resources or are allocated status within society [28]. Gender is about men and women. Men and women are not the same: they are not equal nor will they ever be, due to physical and biological conditions. Even today, the women's position or social status within in the society is different from that of men as shown by part of the feminist theory [29]. The women are looked down upon as weaker sex while men are considered as savior.

\subsubsection{Religion}

Religion is aspect that shapes people's values that will influence how individual acted and directly affects the way the societies operate. slam sees religion as guidance of life based on the Holy Qur'an and the Sunnah of Prophet Muhammad (SAW). The Holy Qur'an is the final revelation from Allah to humanity was revealed by Prophet Muhammad (SAW). It is mentioned that the Holy Quran is not merely to provide divine guidance to worshipping the One and Only God but also to provide extensive information and references concerning religion, religious belief, norms and basic principles relation to various aspects of life. The second source of Muslim guidance to study religion is the Sunnah of the Prophet Muhammad (SAW) as the last messenger of Allah. Sunnah has been defined by scholars "a word spoken or an act done or a conformation given by the Holy Prophet Muhammad (SAW).

\subsection{Empirical Review}

Teixeira and Sharifu [30] assessed the perceptions of female entrepreneurs in Tanzania regarding the access to bank loans and the difficulties experienced in the process of financing their businesses using 75 female entrepreneurs from the Dar Es Salaam area and the study revealed that women who perceive higher discrimination and/or inequality in accessing bank loans, but who also recognize that female entrepreneurs often lack relevant business skills, tend to apply more often for bank loans; women running larger business, operating in the tailoring industry, face fewer difficulties; although highly educated female entrepreneurs apply less for bank loans, formal education acts as a shield to the difficulties faced by women when applying to bank loans; and more autonomous and money seeking female entrepreneurs are less likely to report difficulties during the bank loan application process. The problem with the study is that the real educational motivating factors were not stated.

Urbano, Ferri and Noguera [31] analysed the socio-cultural 
factors that influence the likelihood of women becoming social entrepreneurs, using institutional economics. Binary logistic regression has been applied as the statistical method to test the hypotheses proposed, using data (40 countries and 56,875 individuals) from the World Value Survey (WVS) and the World Bank (WB). The main findings of the study reaffirm the relevance of socio-cultural factors to social entrepreneurship. Particularly, we have found that altruistic attitudes and being a member of a social organization are the most relevant socio-cultural factors for social female entrepreneurship

Roohangiz, Shahin and Hajar [32] determined the sociocultural and economic factors affecting women's entrepreneurship in Khouzestan province and 100 entrepreneurs were selected based on simple random sampling. The measurement instrument of the research was questionnaire and descriptive and analytic procedures were employed. The current research was a correlation type. Data analysis resulted using Pearson and regression coefficient showed that socio-cultural and economic factors had positive effect on women entrepreneurs. The present research revealed that social Factors had more effect on women entrepreneurship in Khouzestan than other factors.

Amodu, Abeh and Audu [33] examined the effects of gender bias and cultural beliefs on women entrepreneurship in Nigeria using 380 women entrepreneurs in three states, North Central Nigeria (i.e., Benue, Kogi and Kwara) and the study adopted descriptive survey design. The findings of the study show that women in Nigeria are affected by a number of cultural factors that impede the growth and development of their entrepreneurial intentions. The problem with the study is that simple descriptive statistics was used to arrive at a conclusion.

Mordi, Simpson, Singh, and Okafor [1] examined the effect of environmental factors on women entrepreneurship development (WED) in Lagos State, Nigeria using both Primary and secondary data and the results revealed that government policy as an environmental factor has negative correlation with women entrepreneurship development and this affects other factors. The problem with the study is that the other factors were not clearly stated at conclusion.

Akpor and Masoje [4] examined the impact of sociocultural environment on entrepreneurial emergence using a survey research design and data were collected through the instruments of questionnaire and personal interview. The study revealed that the Nigerian socio-cultural characteristics, in some ways, have provided impetus for entrepreneurial emergence among Nigerians, but in some other ways, have enormously hindered the emergence of entrepreneurs. This paper concludes that, in general, sociocultural environment significantly impact on entrepreneurial emergence in society. The problem with the study is that the negatively affected areas were not stated at conclusion.

Mordi, Simpson, Singh and Okafor [1] examined the challenges female entrepreneurs face in the development of their business in the context of Nigeria using 274 female entrepreneurs currently engaged in their businesses in three states Lagos, Ogun and Oyo within the south west of Nigeria and the results revealed that female entrepreneurs are generally confident and resourceful and that they enjoy the challenge of entrepreneurial activity. As in the West, they experience difficulties relating to family commitments and access to finance as well as problems gaining acceptance and accessing networks. The problem with the study is that the motivational factors were not stated.

\subsection{Theoretical Framework}

Socio-cultural Theories of Entrepreneurial Emergence

Over the years, a number of theories have been used to explain the impact of socio-cultural environment on entrepreneurial emergence. These theories tried to explain the social and cultural characteristics which cause people to be or not be entrepreneurs. The earliest theory on the influence of socio-cultural environment on entrepreneurship was that of Max Weber, a German sociologist. In his theory, Weber explained that society plays a big role in developing entrepreneurs. This is because the individual draws his values from the social values, more so and institutional framework within which he lives [34]. He argues that culture has great impact on the attitude and behavior of individuals and their disposition to life. And indeed, whether or not an individual would develop and become entrepreneur would depend on his disposition and value orientation. He cited religion as an element of culture, which directly influences the behavior of individuals towards being entrepreneurs. Such religious characteristics as hard work, thrift and an ascetic life of selfdenial are all prescription for entrepreneurship. Essentially, the point of Weber's theory is that the socio-cultural systems in which individuals live provide a set of values from which personal values and thinking pattern of people are based, and these in turn influence the decision by individuals positively or negatively towards entrepreneurship, i.e. whether or not to be entrepreneurs. Fundamentally, social systems and culture affect the development of entrepreneurial spirit and motivation by exhibiting values that either enhance or inhibit entrepreneurship behavior and drive amongst people.

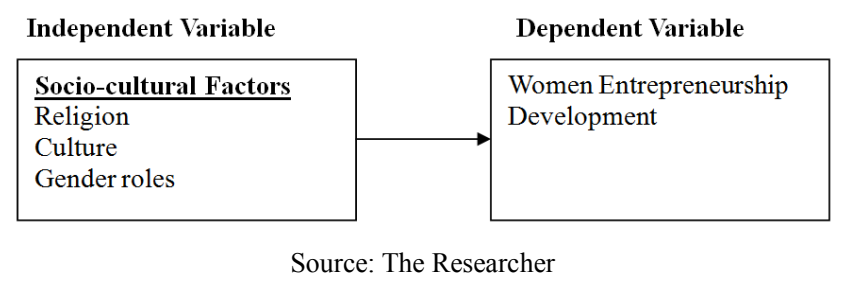

Figure 1. Conceptual Framework.

\section{Methodology}

Descriptive survey research design wasused to carry out the study and the reason is that information needed describes existing phenomena by asking individuals about their perceptions, attitudes, behavior or values [35]. The research is conducted in Kaduna metropolis and is chosen because of its centrality in the Northern region and the area of the study 
due to its cosmopolitan nature. The target population of this study is 332 women entrepreneurs in retail shops, clothes business, service rending businesses and women engage in livestock businesses in Kaduna metropolis and this was used as the sample size of the study. The study employed combination of cluster and simple random sampling; the study area was clustered based on their geographical location, in each location, businesses owned by women were clustered based on business types i.e. retail shops, clothing businesses, Service rendering businesses and livestock businesses. Data is collected using questionnaire because it allows the researcher to reach a large sample within a limited time and the questionnaire is designed in a five-point Likert scale.

Data collection started by proceeding to the field to administer the research instruments. The researchers undertook some reconnaissance prior to the actual study to familiarize them with the study area and build rapport with the respondents after which the Local Government Areas of the state were visited. During the study, the questionnaire is administered to the respondents and collected the following day. For respondents who are illiterate, the researchers explained the questionnaire to them in the language they understand in order to fill them appropriately.

In this study, piloting of the instrument is done in ten (10) business units owned by women that are not included in the study to validate them and to determine their accuracy, clarity and suitability. Piloting of the instrument help in checking how far the measuring instruments served as representative of the full content of the concept being studied. Based on the analysis of the piloting, modification and removal of ambiguous questions, inaccurate responses or indicated weaknesses is done to attract appropriate responses from the respondents. Content validity established through consultations and discussions with the researchers in area of entrepreneurship development.

The reliability of the questionnaire was established through the test-retest procedure. Questionnaire was tested first in ten (10) randomly selected women entrepreneurs not in the study sample. The variables were tested using SPSS version 25 and the result indicates that all the variables are reliable. The study adopted correlation and regression to indicate cause, effect, strength and degree of the relationship between the variables. The model is stated below.

The model of regression was state below:

$$
\begin{aligned}
& \mathrm{WED}=\alpha+\beta_{1} \mathrm{RLN}+\mu \\
& \mathrm{WED}=\alpha+\beta_{1} \mathrm{CLT}+\mu \\
& \mathrm{WED}=\alpha+\beta_{1} \mathrm{ENR}+\mu
\end{aligned}
$$

Where

WED $=$ Women entrepreneurship Development

$\mathrm{RLN}=$ Religion

CLT $=$ Culture

$\mathrm{GNR}=$ Gender role

$\alpha=$ Intercept, $\beta=$ coefficient and $\mu=$ error term

The correlation model is stated below

\begin{tabular}{|c|c|c|c|c|c|}
\hline Items & 5 & 4 & 3 & 2 & 1 \\
\hline The women entrepreneurs initiative business ideas for their enterprises & $88(26.51)$ & $78(23.49)$ & $74(22.29)$ & $69(20.78)$ & $23(6.93)$ \\
\hline Women entrepreneurs organized five M's of management & $112(33.73)$ & 101(30.42) & $60(18.07)$ & $48(14.46)$ & $11(3.31)$ \\
\hline Women entrepreneurs operated successfully their business enterprises & $133(40.06)$ & $111(33.43)$ & $12(3.61)$ & $68(20.48)$ & $8(2.41)$ \\
\hline
\end{tabular}

Data Presentation

Table 1. Women Entrepreneurship.

Source: Survey, 2019

The above indicate the percentages of responses on sport entrepreneurship related question, which is used to compute the

\begin{tabular}{|c|c|c|c|c|c|c|c|c|c|c|c|}
\hline Variables & 5 & 4 & 3 & 2 & 1 & FX & $\mathbf{N}$ & Mean & Remarks & Ranking & Sectorial mean \\
\hline Initiation & 88 & 78 & 74 & 69 & 23 & 1135 & 332 & 3.42 & High & $3^{\text {rd }}$ & \\
\hline Organization & 112 & 101 & 60 & 48 & 11 & 1251 & 332 & 3.77 & High & $2^{\text {nd }}$ & 3.70 \\
\hline Operational & 133 & 111 & 12 & 68 & 8 & 1289 & 332 & 3.88 & High & $1^{\mathrm{st}}$ & \\
\hline
\end{tabular}
mean.

Table 2. Mean of Women Entrepreneurship.

Author's Computation, 2019

The above table indicates that women entrepreneurship is unique since the sectorial mean is more than average. This portrait that there is initiation of ideas, organization of resources, and effective operation of resources by women entrepreneurs and the implication of this is that they are fully

\begin{tabular}{|c|c|c|c|c|c|}
\hline Items & 5 & 4 & 3 & 2 & 1 \\
\hline The values of the society affect business activities & 91(27.41) & 123(37.05) & $18(5.42)$ & $88(26.51)$ & $12(3.61)$ \\
\hline The attitude of people determine the business growth & $112(33.73)$ & $122(36.71)$ & $9(2.71)$ & $77(23.19)$ & $12(3.61)$ \\
\hline Shares norms of the society determine the type of business to operate & $99(29.82)$ & $131(39.46)$ & $11(3.31)$ & $81(24.39)$ & $10(3.01)$ \\
\hline
\end{tabular}
in business.

Table 3. Culture.

Source: Survey, 2019 
The above indicate the percentages of responses on culture related question, which was used to compute the mean.

Table 4. Mean of culture.

\begin{tabular}{|c|c|c|c|c|c|c|c|c|c|c|c|}
\hline Variables & 5 & 4 & 3 & 2 & 1 & FX & $\mathbf{N}$ & Mean & Remarks & Ranking & Sectorial mean \\
\hline Values & 91 & 123 & 18 & 88 & 12 & 1189 & 332 & 3.58 & High & $3^{\text {rd }}$ & \\
\hline Attitudes & 112 & 122 & 9 & 77 & 12 & 1263 & 332 & 3.80 & High & $1^{\text {st }}$ & 3.69 \\
\hline Shares values & 99 & 131 & 11 & 81 & 10 & 1224 & 332 & 3.69 & High & $2^{\text {nd }}$ & \\
\hline
\end{tabular}

Author's Computation, 2019

The above table indicates that poverty eradication as a measured of culture is unique since the sectorial mean is more than average. This portrait that there is standard values, attitude and shares norms and the implication of this is that Niger have a unique culture.

Table 5. Gender Roles.

\begin{tabular}{|c|c|c|c|c|c|}
\hline Items & 5 & 4 & 3 & 2 & 1 \\
\hline Women role of child bearing activities of business and growth & $110(33.13)$ & $99(29.82)$ & $84(25.30)$ & $22(6.63)$ & $17(5.12)$ \\
\hline $\begin{array}{l}\text { Domestic engagement by women in the house affect the time of business } \\
\text { resumption }\end{array}$ & $121(36.45)$ & $122(36.75)$ & $9(2.71)$ & $67(20.18)$ & $13(3.92)$ \\
\hline $\begin{array}{l}\text { Family responsibilities determine the growth of business venture owned by } \\
\text { a women }\end{array}$ & $111(33.43)$ & $101(30.42)$ & $77(23.1)$ & $32(9.64)$ & $11(3.31)$ \\
\hline
\end{tabular}

Survey, 2019

The above indicate the percentages of responses on gender roles related question, which was used to compute the mean.

Table 6. Mean of Gender Roles.

\begin{tabular}{llllllllllll}
\hline Variables & $\mathbf{5}$ & $\mathbf{4}$ & $\mathbf{3}$ & $\mathbf{2}$ & $\mathbf{1}$ & $\mathbf{F X}$ & $\mathbf{N}$ & Mean & Remarks & Ranking & Sectorial mean \\
\hline Child bearing & 110 & 99 & 22 & 84 & 17 & 1197 & 332 & 3.61 & High & $2^{\text {nd }}$ & \\
Domestic engagement & 121 & 122 & 9 & 67 & 13 & 1267 & 332 & 3.82 & High & $1^{\text {st }}$ & 3.70 \\
Family responsibility & 111 & 101 & 32 & 77 & 11 & 1220 & 332 & 3.67 & High & $3^{\text {rd }}$ & \\
\hline
\end{tabular}

Author's Computation, 2019

The above table indicates that gender role unique since the sectorial mean is more than average. This portraits that women have unique roles that affect their business activities and the implication of this is that Kaduna Metropolis has a unique gender roles.

Table 7. Religion.

\begin{tabular}{llllll}
\hline Items & $\mathbf{5}$ & $\mathbf{4}$ & $\mathbf{3}$ & $\mathbf{2}$ & $\mathbf{1}$ \\
\hline Religious believes permit women to establish business ventures & $99(29.82)$ & $131(39.46)$ & $11(3.31)$ & $81(24.39)$ & $10(3.01)$ \\
The religious norms allow women to establish business & $121(36.45)$ & $122(36.75)$ & $9(2.71)$ & $67(20.18)$ & $13(3.92)$ \\
Religious principles ensure that women venture into business & $112(33.73)$ & $101(30.42)$ & $60(18.07)$ & $48(14.46)$ & $11(3.31)$ \\
\hline
\end{tabular}

Survey, 2019

The above indicate the percentages of responses on religion related question which is used to computed the mean.

Table 8. Regression Result 1 .

\begin{tabular}{lllll}
\hline Model Summary & & & & \\
\hline Model & R & R Square & Adjusted R Square & Std. Error of the Estimate \\
\hline 1 & $.070^{\mathrm{a}}$ & .44 & .39 & .96979 \\
\hline
\end{tabular}

a. Predictors: (Constant), RLN

\begin{tabular}{lllllll}
\hline ANOVA $^{\mathbf{a}}$ & & & & & \\
\hline Model & & Sum of Squares & Df & Mean Square & F & Sig. \\
\hline \multirow{3}{*}{1} & Regression & 1.554 & 1 & 1.554 & 111.653 & $.009^{\text {b }}$ \\
& Residual & 316.006 & 331 & .940 & & \\
\hline & Total & 317.560 & 332 & & & \\
\hline
\end{tabular}

a. Dependent Variable: WED

b. Predictors: (Constant), RLN 


\begin{tabular}{|c|c|c|c|c|c|c|}
\hline \multicolumn{7}{|c|}{ Coefficients $^{\mathrm{a}}$} \\
\hline \multirow{2}{*}{\multicolumn{2}{|c|}{ Model }} & \multicolumn{2}{|c|}{ Unstandardized Coefficients } & $\begin{array}{l}\text { Standardized } \\
\text { Coefficients }\end{array}$ & \multirow[t]{2}{*}{$\mathbf{T}$} & \multirow[t]{2}{*}{ Sig. } \\
\hline & & B & Std. Error & Beta & & \\
\hline \multirow{2}{*}{1} & (Constant) & 3.064 & .162 & & 18.941 & .000 \\
\hline & $\mathrm{PE}$ & .069 & .054 & -.070 & 11.286 & .009 \\
\hline
\end{tabular}

a. Dependent Variable: WED

Decision rule: $5 \%$

The analysis indicates that the coefficient for religion is significant in enhancing women entrepreneurship in Kaduna metropolis. The $\mathrm{p}$-value and t-statistic value of the independent variable is significant at probability value of 0.000 . However, the f-statistic value of 111.653 is significant at $\mathrm{p}$ statistic value of 0.00 ; it indicates that the model is a good fit. The $\mathrm{R}^{2}=0.43$ indicates that only $43 \%$ of business activities embarked upon by women entrepreneurs in Kaduna metropolis can be explain by social development but $57 \%$ can explained by other factors not noted in the regression model which is refer to as error term. Therefore, we accept the alternative hypothesis that there is a significant relationship between women entrepreneurship and religious in Kaduna metropolis.

Table 9. Regression Result 2.

\begin{tabular}{|c|c|c|c|c|c|c|}
\hline \multicolumn{7}{|c|}{ Model Summary } \\
\hline Model & $\mathbf{R}$ & R Square & & Adjusted R Square & \multicolumn{2}{|c|}{ Std. Error of the Estimate } \\
\hline 1 & $016^{\mathrm{a}}$ & 61 & & 53 & 97205 & \\
\hline \multicolumn{7}{|c|}{ a. Predictors: (Constant), CLT } \\
\hline \multicolumn{7}{|c|}{ ANOVA $^{a}$} \\
\hline \multicolumn{2}{|c|}{ Model } & Sum of Squares & Df & Mean Square & $\mathbf{F}$ & Sig. \\
\hline \multirow{3}{*}{1} & Regression & 082 & 1 & 082 & 121.087 & $008^{\mathrm{b}}$ \\
\hline & Residual & 317.478 & 331 & .945 & & \\
\hline & Total & 317.560 & 332 & & & \\
\hline
\end{tabular}

a. Dependent Variable: WED

b. Predictors: (Constant), CLT

\begin{tabular}{lllllll}
\hline Coefficients $^{\mathbf{a}}$ & & & & \\
\hline \multirow{2}{*}{ Model } & & \multicolumn{2}{l}{ Unstandardized Coefficients } & Standardized Coefficients & \multirow{2}{*}{ T } & \\
\cline { 2 - 5 } & & B & Std. Error & Beta & & \\
\hline \multirow{2}{*}{1} & (Constant) & 2.914 & .164 & & 17.781 & .000 \\
& $\mathrm{E}$ & .1016 & .054 & -.016 & .295 & .008 \\
\hline
\end{tabular}

a. Dependent Variable: WED

Decision rule: $5 \%$

The analysis indicates that the coefficient for culture is significant in enhancing women entrepreneurship in Kaduna metropolis. The p-value and t-statistic value of the independent variable is significant at probability value of 0.000 . However, the f-statistic value of 121.087 is significant at $\mathrm{p}$ statistic value of 0.00 ; it indicates that the model is a good fit. The $\mathrm{R}^{2}=0.61$ indicates that only $61 \%$ of business activities embarked upon by women entrepreneurs in Kaduna metropolis can be explain by culture but $39 \%$ can explained by other factors not noted in the regression model which is refer to as error term. Therefore we accept the alternative hypothesis that there is a significant relationship between women entrepreneurship and culture in Kaduna metropolis.

Table 10. Regression Result 3.

\begin{tabular}{lllll}
\hline Model Summary & & & \\
\hline Model & R & R Square & Adjusted R Square & Std. Error of the Estimate \\
\hline 1 & $.16^{\mathrm{a}}$ & .451 & .343 & .87205 \\
\hline
\end{tabular}

a. Predictors: (Constant), ENR

\begin{tabular}{lllllll}
\hline ANOVA $^{\mathbf{a}}$ & & & & & \\
\hline Model & & Sum of Squares & Df & Mean Square & F & Sig. \\
\hline \multirow{2}{*}{1} & Regression & .082 & 1 & .081 & 131.017 & $.001^{\text {b }}$ \\
& Residual & 311.418 & 331 & .341 & & \\
& Total & 311.160 & 332 & & & \\
\hline
\end{tabular}

a. Dependent Variable: WED

b. Predictors: (Constant), ENR 


\begin{tabular}{|c|c|c|c|c|c|c|}
\hline \multicolumn{7}{|c|}{ Coefficients $^{\mathrm{a}}$} \\
\hline \multirow{2}{*}{\multicolumn{2}{|c|}{ Model }} & \multicolumn{2}{|c|}{ Unstandardized Coefficients } & \multirow{2}{*}{$\begin{array}{l}\text { Standardized Coefficients } \\
\text { Beta }\end{array}$} & \multirow{2}{*}{$\mathbf{T}$} & \multirow{2}{*}{ Sig. } \\
\hline & & B & Std. Error & & & \\
\hline \multirow{2}{*}{1} & (Constant) & 2.114 & .174 & & 15.711 & .000 \\
\hline & $\mathrm{E}$ & .1116 & .054 & -.116 & .195 & .001 \\
\hline
\end{tabular}

a. Dependent Variable: WED

Decision rule: $5 \%$

The analysis indicates that the coefficient for gender role is significant in enhancing women entrepreneurship in Kaduna metropolis. The $\mathrm{p}$-value and t-statistic value of the independent variable is significant at probability value of 0.000 . However, the f-statistic value of 131.017 is significant at $p$ statistic value of 0.00 , it indicates that the model is a good fit. The $\mathrm{R}^{2}=0.45$ indicates that only $45 \%$ of business activities embarked upon by women entrepreneurs in Kaduna metropolis can be explain by gender roles but $39 \%$ can explained by other factors not noted in the regression model which is refer to as error term. Therefore we accept the alternative hypothesis that there is a significant relationship between women entrepreneurship and gender role in Kaduna metropolis.

\section{Discussion of Findings}

From the analysis, there is significant relationship between socio-cultural factor and women entrepreneurship development in Kaduna metropolis. Specifically, there is significant relationship among religion, culture and gender role and women entrepreneurship development in Kaduna metropolis. The finding is in tandem with the findings of [32] who found that there is significant relationship between these variables and women entrepreneurship development. The study is in line with the socio-cultural theory of entrepreneurship.

\section{Conclusions and Recommendations}

The study concluded that there is significant relationship between socio-cultural factors and women entrepreneurship development in Kaduna metropolis. In addition, there is significant relationship between religion and women entrepreneurship in Kaduna metropolis. The study also concluded that they there is a significant relationship between culture and women entrepreneurship in Kaduna metropolis. The study also concluded that there is a significant relationship between gender role and women entrepreneurship development in Kaduna metropolis. The study however recommends that women entrepreneurs in Kaduna metropolis should be proactive in doing business by bearing in mind various socio-cultural factors such as religion, culture and gender roles that may hinder the smooth running of their businesses.

\section{References}

[1] Mordi, C., Simpson, R. Singh, S. \& Okafor, C. (2010). The role of cultural values in understanding the challenges faced by female entrepreneurs in Nigeria. Gender in Management: An International Journal, 25 (1), 5-21.
[2] Anggadwita, G., Luturlean, B. S., Ramadani, V., \& Ratten, V. (2017). Socio-cultural environments and emerging economy entrepreneurship: Women entrepreneurs in Indonesia. Journal of Entrepreneurship in Emerging Economies, 9 (1), 85-96.

[3] Eijdenberg, E. L., \& Masurel, E. (2013). Entrepreneurial motivation in a least developed country: Push factors and pull factors among MSEs in Uganda. Journal of Enterprising Culture, 21 (01), 19-43.

[4] Akpor, R. \& Masoje, O. M. (2012). The impact of sociocultural environment on entrepreneurial emergence: An empirical analysis of Nigeria society. Management Science and Engineering, 6 (4), 83-93.

[5] Abimbola, O. H. \& Agboola, M. G. (2011). Environmental factors and entrepreneurship development in Nigeria. Journal of Sustainable Development in Africa, 13 (4), 23-32.

[6] Mathew, V. (2019). Women Entrepreneurship in Gulf Region: Challenges and Strategies In GCC. International Journal of Asian Business and Information Management (IJABIM), 10 (1), 94-108.

[7] Yusuf, L. (2013). Influence of Gender and Cultural Beliefs on women Entrepreneurs in Developing Economy, Scholarly Journal of Business Administration Vol. 3 (5) 117-119.

[8] Halkias, D., Nwajiuba, C., Harkiolakis, N., \& Caracatsanis, S. M. (2011). Challenges facing women entrepreneurs in Nigeria. Management Research Review, 34 (2), 221-235.

[9] Aderinto, C. O., David, J. O., \& Alabi, F. A. (2018). Cultural Values and the Development of Women Entrepreneurs in South Western Nigeria. World Journal of Entrepreneurial Development Studies, 2 (3), 22-33.

[10] Ugwa, M., Okonkwo, C. J., \& IGWEGBE, D. O. (2019). Influence of Culture on Women Entrepreneurship in Nigeria. Forschen Hub International Journal of Economics and Business Management, 1 (1), 1-12.

[11] Klapper, L. F. and Parker, S. C. (2011) 'Gender and the business environment for new firm creation', The World Bank Research Observer, Vol. 26 No. 2, pp. 237-257.

[12] Nukpezah, J. A. \& Blankson, C. (2017). Microfinance intervention in poverty reduction: A study of women farmerentrepreneurs in rural Ghana. Journal of African Business, Article in Press.

[13] Goyal, M., \& Parkash, J. (2011). Women entrepreneurship in India-problems and prospects. International journal of multidisciplinary research, 1 (5), 195-207.

[14] Kumar, S. M., Mohan, H. C., Vijaya, C., \& Lokeshwari, N. (2013). The role of women entrepreneurship in modern world. International Journal of Current Engineering and Technology, 1 (Special Issue), 100-104.

[15] Kpelai, S. T. (2013). The Impact of Women Entrepreneurship on Economic Growth in Benue State of Nigeria. IOSR Journal of Business and Management, 13 (1), 07-12. 
[16] Adeleke, A., Oyenuga, O. O. \& Ogundele, O. J. K. (2003). Business Policy and Strategy. Mushin, Lagos: Concept Publications Limited.

[17] Hofstede, G. (1980). Culture and organizations. International Studies of Management \& Organization, 10 (4), 15-41.

[18] Adler, N. J. (1997). International Dimensions of Organizational Behavior, 3rd edn. Cincinnati, OH: SouthWestern College Publishing.

[19] Weber, M. (1976). The Protestant Ethic and the Spirit of Capitalism London: Allen and Urwin.

[20] Fukuyama, F. (1995). The Great Disruption Trust: The Social Values and the Creation of Prosperity. New York: The Free Press.

[21] Inglehart, R. (2000). Culture and Democracy. In Harrison, L. E; Huntington, S. P. (eds) Culture Matters Basic Books.

[22] Connell, R. W. (2002). Gender Short Introductions.

[23] Kochan, T., Bezrukova, K., Ely, R., Jackson, S., Joshi, A., Jehn, K., Leonard, J., Levine, D., \& Thomas, D. (2003). The effects of diversity on business performance: Report of the diversity research network. Human Resource Management, 42: 3-21.

[24] UN - Habitat. (2004). The challenge of slums: Global report on human settlements 2003. Management of Environmental Quality: An International Journal, 15 (3), 337-338.

[25] Riley, N. E. (1997). Gender, power and population change. Population Bulletin, 52 (1), 2-48.

[26] Ostergaard, L. (1992). Gender and development: A practical guide. London: Routledge.
[27] Sen, G. (1999). A Quick Guide to Gender Mainstreaming in Finance (Vol. 5). Commonwealth Secretariat.

[28] Barriteau, E. (1998). Theorizing Gender Systems and the Project of Modernity in the Twentieth-Century Caribbean. Feminist Review, (59), 186-210. Retrieved from http://www.jstor.org/stable/1395730.

[29] Hearn, J., \& Morgan, D. H. J. (2014). Men, Masculinities and Social Theory (RLE Social Theory). Routledge.

[30] Teixeira, A. A. C. \&Sharifu, H. A. (2017). Female entrepreneurship and access to bank loans in Tanzania: A double-hurdle model approach. Journal of Developmental Entrepreneurship, 22 (3), 1-29.

[31] Urbano, D., Jiménez, E. F., \& iNoguera, M. N. (2014). Female social entrepreneurship and socio-cultural context: an international analysis. Revista de Estudios Empresariales. Segundaépoca, (2), 26-40.

[32] Roohangiz, N., Shahin, R. \& Hajar, A. (2012). A Survey on Socio-Cultural and Economical Factors Affecting Women Entrepreneurs InKhouzestan Province. Australian Journal of Basic and Applied Sciences, 6 (13): 11-17.

[33] Amodu, A. \& Audu, (2015). Effects of gender and cultural beliefs on women entrepreneurship in Nigeria. Proceedings of The IRES 19th International Conference, Dubai, UAE, 5th December 2015, ISBN: 978-93-85832-64-2.

[34] Van de Ven, A. H. (1993). The Development of an Infrastructure for Entrepreneurship. Journal of Business Venturing, May.

[35] Mugenda, O. \& Mugenda, A. G. (2006). Research methods: Quantitative and Qualitative methods. Nairobi: Nairobi ACTS press. 